\title{
Apparent Molal Volume of Aqueous Solutions of Propanoic Acid, Butanoic Acid, Isobutanoic Acid, and their Sodium Salts at Pressures up to 2000 bar at $25^{\circ} \mathrm{C}$
}

\author{
H A R A L D H Ø I L A N D \\ Department of Chemistry, University of Bergen, N-5014 Bg.U, Norway

\begin{abstract}
The compressions of aqueous solutions of propanoic acid, butanoic acid, and isobutanoic acid and their sodium salts were measured at pressures up to 2000 bar at $25^{\circ} \mathrm{C}$. The apparent molal volume of the aqueous solutions of the carboxylic acids and their sodium salts was calculated from existing density values.

The apparent molal volume has been separated into three contributions: the intrinsic volume of the molecule, the volume due to hydrophilic hydration, and the volume due to hydrophobic hydration. When the hydrocarbon chain contains more than two carbon atoms, the volume due to hydrophilic hydration seems to become constant, independent of the length of the hydrocarbon chain. The volume increment from the addition of a $\mathrm{CH}_{2}$-group is mainly due to the volume of the $\mathrm{CH}_{2}$-group itself. The volume due to hydrophobic hydration is independent of pressure.

The partial molal volume of ionization is probably dependent on the conditions around the carboxylic group, and seems to approach a constant value as the hydrocarbon chain increases.
\end{abstract}

The apparent molal volume of solutions of electrolytes at infinite dilution 1 has been investigated by a number of workers studying solute-solvent and solvent-solvent interactions. ${ }^{1}$

It seems likely that the apparent molal volume of solutions at finite concentration might provide valuable information as well. In this work the apparent molal volume and its dependence on pressure at a concentration of approximately 0.5 molal, have been used in studying structural relations in aqueous solution.

\section{EXPERIMENTAL}

The compression cell was made from an ordinary Pyrex glass cell with two fixed electrodes. A tube of approximately $4 \mathrm{~mm}$ diameter and length $12 \mathrm{~cm}$ was connected to this cell, Fig. 1. A spiral of $0.2 \mathrm{~mm}$ platinum wire was soldered on a small stainless steel cylinder forming a floating electrode on top of the mercury meniscus in the tube, the 


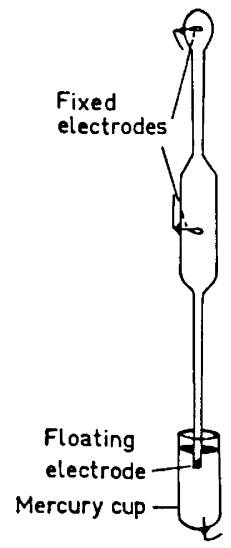

Fig. 1. Compression and conductivity cell.

mercury acting both as pressure transmitting fluid and as electrical lead for the floating electrode.

From the measured conductivity the cell constant between each of the fixed electrodes and the floating electrode was calculated at each pressure. The compression $k$ was then calculated from an empirical equation

$$
k=\alpha\left(K_{\mathrm{p}}-K_{\mathrm{o}}\right) / V_{0}
$$

Here $K_{\mathrm{p}}$ and $K_{0}$ represent the cell constants between one of the fixed electrodes and the floating electrode at pressure $p$ and atmospheric pressure, respectively. $V_{0}$ is the starting volume of the cell and $\alpha$ a constant determined from measurements on the compression of dilute electrolyte solution using the values of Gibson and Loeffler ${ }^{2}$ on the compression of water as calibrating standard. Parallel measurements indicated an error of \pm 0.0002 in the compression values. Good results were obtained both with rising and falling pressures except at the lower pressures where hysteresis appeared.

Materials. The water used had conductivity less than $4 \times 10^{-6} \mathrm{ohm}^{-1} \mathrm{~cm}^{-1}$. The propanoic acid was made by E. Merck A.G., the butanoic acid by The British Drug Houses Ltd., and the isobutanoic acid by Fluka AG, quality puriss. The acids were used without further purification. Sodium salts were prepared by titration by weight with sodium hydroxide solution. The conductivity of the butanoic acid solution was compared with values given by Grindley and Bury, ${ }^{3}$ the difference being approximately $0.3 \%$.

Density. The density values were taken from King ${ }^{4}$ and International Critical Tables. ${ }^{5}$ The compression values of acetic acid were taken from Korpela ${ }^{6}$ by interpolation.

The error in the apparent molal volumes due to errors in density and compression values is estimated to $\pm 0.1 \mathrm{~cm}^{3} / \mathrm{mol}$.

\section{RESULTS}

From Figs. 2 and 3 it is seen that the apparent molal volume of the aqueous solutions of acetic acid, propanoic acid, butanoic acid, and isobutanoic acid decreases with increasing pressure while the apparent molal volume of the salts increases. This seems to be a general result and is explained by the electrostriction due to ion-water interactions. ${ }^{7,8}$

The apparent molal volume of one acid solution is now subtracted from the apparent molal volume of the acid having one carbon atom more in the 

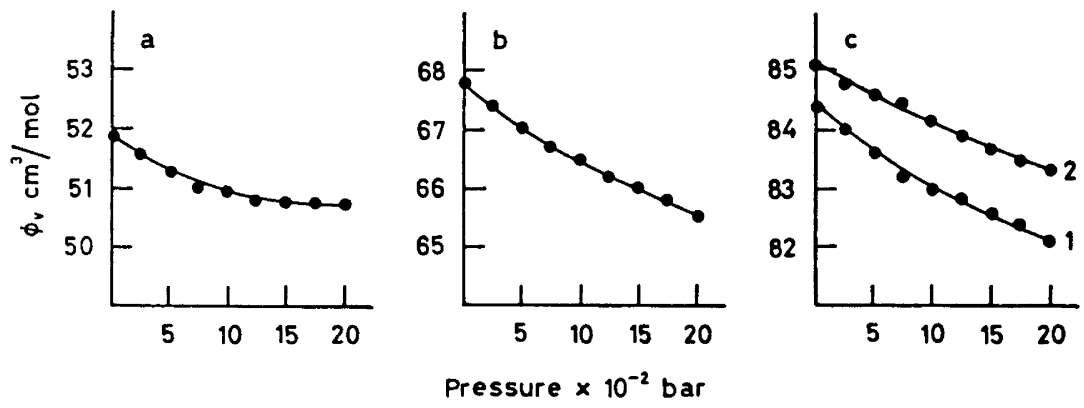

Fig. 2. a. Apparent molal volume of $0.5773 \mathrm{~m}$ acetic acid. b. Apparent molal volume of $0.6881 \mathrm{~m}$ propanoic acid. c. Apparent molal volumes. $1,0.5606 \mathrm{~m}$ butanoic acid. $2,0.5583$ $\mathrm{m}$ isobutanoic Acid.

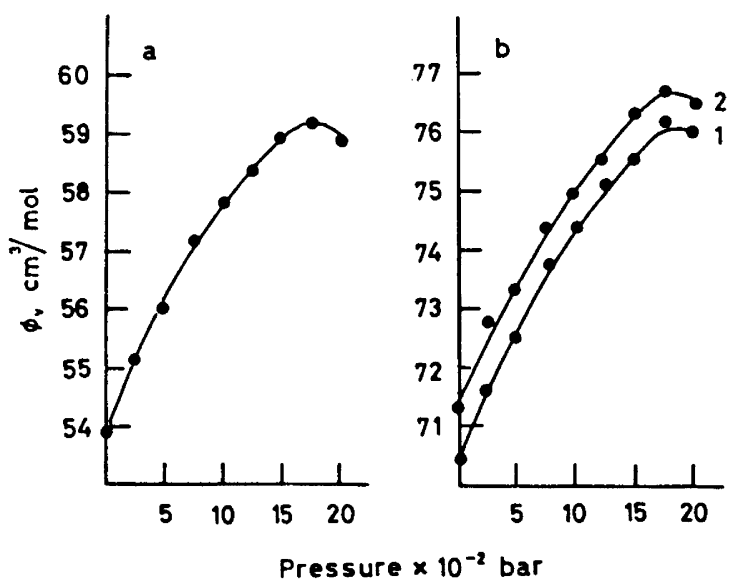

Fig. 3. a. Apparent molal volume of $0.5069 \mathrm{~m}$ sodium propanoate. b. Apparent molal volumes. $1,04395 \mathrm{~m}$ sodium butanoate. $2,0.4324 \mathrm{~m}$ sodium isobutanoate.

hydrocarbon chain. The overall volume increment due to the addition of a $\mathrm{CH}_{2}$-group is then found:

$$
\Delta \phi_{\mathrm{v}}(m, m-1)=\phi_{\mathrm{v}}(m)-\phi_{\mathrm{v}}(m-1)
$$

Here $m$ and $m-1$ are the number of carbon atoms in the hydrocarbon chain of the two carboxylic acids.

The same was done with the apparent molal volumes of the sodium salt solutions. The contribution of the sodium ions cancels, and one is left with the overall volume increment of adding a $\mathrm{CH}_{2}$-group to the carboxylic anion. The results are given in Tables 1 and 2 . 
Table 1. Differences in the apparent molal volumes between solutions of carboxylic acids, $\Delta \phi_{\mathrm{v}}(m, m-1)$. The numbers in the brackets of $\Delta \phi_{\mathrm{v}}(m, n)$ refer to the number of carbon atoms in the hydrocarbon chain of the two acids in question. The asterisk refers to isobutanoic acid.

\begin{tabular}{rcccc}
\hline $\begin{array}{c}\text { Pressure } \\
\text { bar }\end{array}$ & $\begin{array}{c}\Delta \phi_{\mathrm{v}}(2,1) \\
\mathrm{cm}^{3} / \mathrm{mol}\end{array}$ & $\begin{array}{c}\Delta \phi_{\mathrm{v}}(3,2) \\
\mathrm{cm}^{3} / \mathrm{mol}\end{array}$ & $\begin{array}{c}\Delta \phi_{\mathrm{v}}(4,3) \\
\mathrm{cm}^{3} / \mathrm{mol}\end{array}$ & $\begin{array}{c}\Delta \phi_{\mathrm{v}}\left(4^{*}, 3\right) \\
\mathrm{cm}^{3} / \mathrm{mol}^{3}\end{array}$ \\
\hline 1 & 17.3 & 15.9 & 16.6 & 17.3 \\
500 & & 15.7 & 16.5 & 17.6 \\
1000 & & 15.6 & 16.5 & 17.6 \\
1500 & & 15.2 & 16.6 & 17.6 \\
2000 & & 14.9 & 16.5 & \\
\hline
\end{tabular}

Table 2. Differences in the apparent molal volumes between solutions of the sodium salts of carboxylic acids, $\Delta \phi_{\mathrm{v}}(m, m-1)$. The numbers in the brackets of $\Delta \phi_{\mathrm{v}}(m, n)$ refer to the number of carbon atoms in the hydrocarbon chain of the two acid anions in question. The asterisk refers to isobutanoate.

\begin{tabular}{rcccc}
\hline $\begin{array}{c}\text { Pressure } \\
\text { bar }\end{array}$ & $\begin{array}{c}\Delta \phi_{\mathrm{v}}(2,1) \\
\mathrm{cm}^{3} / \mathrm{mol}\end{array}$ & $\begin{array}{c}\Delta \phi_{\mathrm{v}}(3,2) \\
\mathrm{cm}^{8} / \mathrm{mol}\end{array}$ & $\begin{array}{c}\Delta \phi_{\mathrm{v}}(4,3) \\
\mathrm{cm}^{3} / \mathrm{mol}\end{array}$ & $\begin{array}{c}\Delta \phi_{\mathrm{v}}\left(4^{*}, 3\right) \\
\mathrm{cm}^{3} / \mathrm{mol}^{3}\end{array}$ \\
\hline 1 & 14.3 & 13.4 & 16.5 & 17.4 \\
500 & & & 16.5 & 17.4 \\
1000 & & & 16.5 & 17.3 \\
1500 & & 16.6 & 17.4 \\
2000 & & & 16.2 & 17.6 \\
\hline
\end{tabular}

When $m$ in eqn. 2 takes the values $4, \Delta \phi_{\mathrm{v}}(m, m-1)$ is equal for the acid and salt solutions within the limits of error and is independent of pressure.

The values of $\Delta \phi_{\mathrm{v}}(m, m-1)$ are in good agreement with Traube's rule, ${ }^{9}$ predicting an increment of $16.0 \mathrm{~cm}^{3}$ per $\mathrm{CH}_{2}$-group. A somewhat larger increment is observed with the isobutanoic acid. This may be explained by a larger "empty volume"10 due to the two $\mathrm{CH}_{3}$-groups at the hydrocarbon end.

The volume increments per $\mathrm{CH}_{2}$-group of pure liquid carboxylic acids and hydrocarbons are also of the same magnitude (Table 3).

Table 3. Differences in partial molal volumes of pure liquids $\bar{V}=M / d_{4}{ }^{20}$. Density values $d_{4}{ }^{20}$ from Handbook of Chemistry and Physics, 5lst. Ed., The Chemical Rubber Co, Cleveland, Ohio 1970-1971.

$\bar{V}(2,1) \quad \bar{V}$ (Acetic acid) $-\bar{V}$ (Formic acid)

$\bar{V}(3,2) \quad \bar{V}$ (Propanoic acid) $-\bar{V}$ (Acetic acid)

$\bar{V}(4,3) \quad \bar{V}$ (Butanoic acid) $-\bar{V}$ (Propanoic acid)

$\bar{V}\left(4^{*}, 3\right) \quad \bar{V}$ (Isobutanoic acid) $-\bar{V}$ (Propanoic acid)

$\bar{V}(\mathbf{7}, \mathbf{6}) \quad \bar{V}$ (Heptane $)-\bar{V}$ (Hexane)

$\bar{V}(8,7) \quad \bar{V}($ Octane $)-\bar{V}($ Heptane $)$
$19.54 \mathrm{~cm}^{3} / \mathrm{mol}$

$17.36 \mathrm{~cm}^{3} / \mathrm{mol}$

$17.40 \mathrm{~cm}^{3} / \mathrm{mol}$

$16.41 \mathrm{~cm}^{3} / \mathrm{mol}$

$15.3 \quad \mathrm{~cm}^{3} / \mathrm{mol}$

$16.1 \mathrm{~cm}^{3} / \mathrm{mol}$ 
The standard partial molal volume of ionization

$$
\Delta \bar{V}^{\mathrm{o}}=-R T\left(\frac{\partial \ln K}{\partial P}\right)_{T}
$$

was calculated by the method used by Lown, Thirsk and Lord Wynne-Jones.11 The pressure dependence of the activity coefficients was neglected, however. Comparing the results with literature values, ${ }^{4,16}$ it seems that this may be done without appreciable error in the $\Delta \bar{V}^{\mathrm{o}}$ values.

The equivalent conductivities are shown as functions of pressure in Fig. 4. Limiting conductivities were taken from Ellis, ${ }^{12}$ Belcher, ${ }^{13}$ and Dippy. ${ }^{14}$

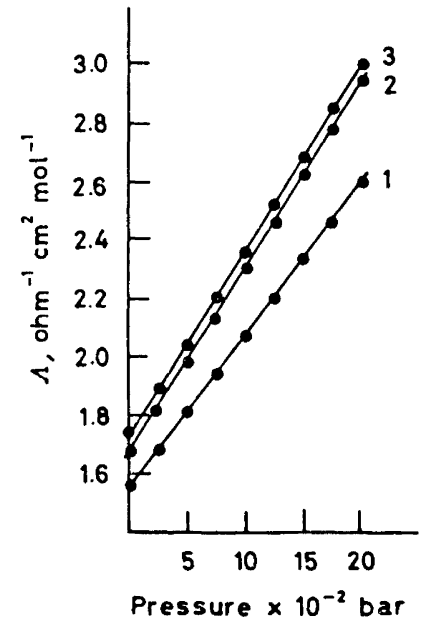

Fig. 4. Equivalent conductivities. 1, 0.6881 $\mathrm{m}$ propanoic acid. $2,0.5583$ isobutanoic acid. $3,0.5606 \mathrm{~m}$ butanoic acid.

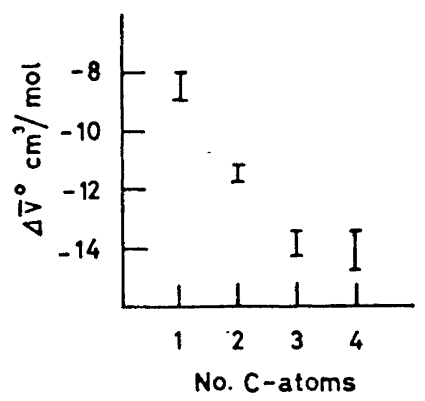

Fig. 2. Standard partial molal volumes of ionization.

Table 4. Standard partial molal volumes of ionization.

\begin{tabular}{|c|c|c|c|c|c|}
\hline $\begin{array}{l}\text { Formic } \\
\text { acid } \\
\mathrm{cm}^{3} / \mathrm{mol}\end{array}$ & $\begin{array}{l}\text { Acetic } \\
\text { acid } \\
\mathrm{cm}^{3} / \mathrm{mol}\end{array}$ & $\begin{array}{l}\text { Propanoic } \\
\text { acid } \\
\mathrm{cm}^{3} / \mathrm{mol}\end{array}$ & $\begin{array}{c}\text { Butanoic } \\
\text { acid } \\
\mathrm{cm}^{3} / \mathrm{mol}\end{array}$ & $\begin{array}{c}\text { Isobutanoic } \\
\text { acid } \\
\mathrm{cm}^{3} / \mathrm{mol}\end{array}$ & Ref. \\
\hline $\begin{array}{l}-8.43 \\
-8.0 \\
-9.2\end{array}$ & $\begin{array}{l}-11.50 \\
-12.5 \\
-11.6 \\
-11.46 \\
-11.47 \\
-11.2\end{array}$ & -14.1 & $\begin{array}{l}-14.22 \\
-13.7\end{array}$ & -14.8 & $\begin{array}{c}4 \\
16 \\
17 \\
18 \\
19 \\
11 \\
\text { This } \\
\text { work }\end{array}$ \\
\hline
\end{tabular}

Acta Chem. Scand. 27 (1973) No. 8 
Values of $\Delta \bar{V}^{\mathrm{o}}$ are given in Table 4 . In Fig. 5 the values of the partial molal volume of ionization are plotted versus the number of carbon atoms in the hydrocarbon chain. It seems to approach a constant value with increasing length of the hydrocarbon chain.

\section{DISCUSSION}

The apparent molal volume may be written as the sum of two terms, first the volume due to the space occupied by the molecule or ion itself $\phi_{\mathrm{v}}(\mathrm{Mol})$ and the overall volume effect due to hydration $\phi_{\mathrm{v}}(\mathrm{H})$.

$$
\phi_{\mathrm{v}}=\phi_{\mathrm{v}}(\mathrm{Mol})+\phi_{\mathrm{v}}(\mathrm{H})
$$

Two main types of hydration are described by Desnoyers and Jolicoeur. ${ }^{15}$ Hydrophilic hydration is caused by the strong affinity existing between polar groups or ions and the solvent. Hydrophobic hydration results from strengthening the solvent-solvent interactions brought about by hydrophobic groups in the molecule. By this model hydrophilic hydration is expected at the carboxylic end and hydrophobic hydration at the hydrocarbon end of the carboxylic acids in aqueous solution.

Eqn. (5) may then be written as

$$
\phi_{\mathrm{v}}=\phi_{\mathrm{v}}(\mathrm{Mol})+\phi_{\mathrm{v}}(1)+\phi_{\mathrm{v}}(2)
$$

where $\phi_{\mathrm{v}}(1)$ and $\phi_{\mathrm{v}}(2)$ refer to the volume contributions of hydrophilic and hydrophobic hydration. Any volume effect due to electrostriction will have to be included in the hydrophilic term, $\phi_{\mathrm{v}}(1)$.

Eqn. (2) may now be written

$$
\Delta \phi_{\mathrm{v}}(m, m-1)=\Delta \phi_{\mathrm{v}}(\mathrm{Mol})+\Delta \phi_{\mathrm{v}}(1)+\Delta \phi_{\mathrm{v}}(2)
$$

where $\Delta \phi_{\mathrm{v}}(\mathrm{Mol})$ is the volume of the added $\mathrm{CH}_{2}$-group.

$$
\Delta \phi_{\mathrm{v}}(m, m-1)=\phi_{\mathrm{v}}\left(\mathrm{CH}_{2}\right)+\Delta \phi_{\mathrm{v}}(1)+\Delta \phi_{\mathrm{v}}(2)
$$

By this hydration model, the addition of a $\mathrm{CH}_{2}$-group has no effect on the volume due to hydrophilic hydration. This may be a realistic model provided that the carbon chain is not too short. This makes $\Delta \phi_{\mathrm{v}}(1)=0$.

$$
\Delta \phi_{\mathrm{v}}(m, m-1)=\phi_{\mathrm{v}}\left(\mathrm{CH}_{2}\right)+\Delta \phi_{\mathrm{v}}(2)
$$

The effect of pressure on the apparent molal volume difference is

$$
\left[\frac{\partial \Delta \phi_{\mathrm{v}}(m, m-1)}{\partial p}\right]_{T}=\left[\frac{\partial \phi_{\mathrm{v}}\left(\mathrm{CH}_{\mathbf{2}}\right)}{\partial p}\right]_{T}+\left[\frac{\partial \Delta \phi_{\mathrm{v}}(2)}{\partial p}\right]_{T}
$$

Regarding the molecule as incompressible, the first term on the right of eqn. (10) is zero, and from Tables 1 and 2 it is seen that the second term must also be zero. Thus, the volume effects of hydrophobic hydration are independent of pressure at least over moderate pressures.

Acknowledgements. This work was supported by a grant from the Norwegian Research Council for Science and the Humanities. I also wish to thank Professor Dr. Thorvald Brun for his valuable advice and his interest in this work. 


\section{REFERENCES}

1. Millero, F. J. Chem. Rev. 71 (1971) 147.

2. Gibson, R. E. and Loeffler, O. H. J. Am. Chem. Soc. 63 (1941) 898.

3. Grindley, J. and Bury, C. R. J. Chem. Soc. 19301665.

4. King, E. J. J. Phys. Chem. 73 (1969) 1220.

5. International Critical Tables, Vol. III McGraw, N. Y. 1933.

6. Korpela, J. Acta Chem. Scand. 25 (1971) 2852.

7. Hamann, S. D. Physico.Chemical Effects of Pressure, Butterworths, London 1957.

8. Yayanos, A. A. J. Phys. Chem. 76 (1972) 1783.

9. Traube, J. Samml. Chem. Vortr. 4 (1899) 255.

10. Edward, J. T. J. Chem. Educ. 47 (1970) 261.

11. Lown, D. A., Thirsk, H. R. and Lord Wynne-Jones Trans. Faraday Soc. 66 (1970) 51.

12. Ellis, A. J. J. Chem. Soc. 19593689.

13. Belcher, D. J. Am. Chem. Soc. 60 (1938) 2744.

14. Dippy, J. F. S. J. Chem. Soc. 19381222.

15. Desnoyers, J. E. and Jolicoeur, C. In Bockris, J. O'M. and Conway, B. E., Eds., Modern Aspects of Electrochemistry, Butterworths, London 1968, No. 5.

16. Hamann, S. D. and Lim, S. C. Aust. J. Chem. 7 (1954) 329.

17. Disteche, L. and Disteche, P. J. Electrochem. Soc. 112 (1965) 350.

18. Wirth, H. J. Am. Chem. Soc. 70 (1948) 462.

19. Redlich, O. and Nielsen, L. E. J. Am. Chem. Soc. 54 (1942) 761.

Received March 12, 1973. 